\title{
Oleoresin yield of Pinus elliottii Engelm seedlings
}

\section{Alfredo Gui Ferreira', Claudimar Sidnei Fior²; Sonia Cristina Juliano Gualtieri ${ }^{3}$}

\author{
1 Universidade Federal do Rio Grande do Sul \& Departamento de Botânica, Universidade Federal de São Carlos; \\ Porto Alegre, Brasil \\ 2 Programa de Pós-Graduação em Fitotecnia, Universidade Federal do Rio Grande do Sul, 91540-000, Porto Alegre, \\ Brasil \\ ${ }^{3}$ Departamento de Botânica, Universidade Federal de São Carlos, Brasil.
}

*Corresponding author: +55 51-37797578; e-mail: alfredo_gui_ferreira@yahoo.com.br

Received: 28 July 2011; Accepted: 29 January 2012

\begin{abstract}
Pinus elliottii is a fast-growing conifer well adapted to southern Brazil, used for wood fiber and resin production. Oleoresin production is part of the plant's defense systems and is induced by ethylene, which production is stimulated by hypoxic conditions. The experiment was designed with the goal of verifying whether one year-old plants had measurable oleoresin yield and if flooding led to increased oleoresin production. There was an increase of $78 \%$ in oleoresin production after 14 to 21 days of flooding and plants with larger stem diameters were more productive.
\end{abstract}

Key-words: flooding, defense mechanisms slash pine.

\section{RESUMO}

Pinus elliottii é uma conífera de rápido crescimento usada para produção de fibras de madeira e para resinas no sul do Brasil. A produção de oleoresinas é parte do sistema de defesas da planta e é regulada por etileno, cuja a produção é estimulada em condições de hipoxia. Com os objetivos de verificar se as plantas com cerca de um ano já produziam níveis mensuráveis de resinas e se estes respondiam ao alagamento é que esse estudo foi realizado. Houve um aumento de até $78 \%$ de produção de resina entre 14 e 21 dias após 0 alagamento induzido e, plantas com maior diâmetro de caule foram as mais produtivas.

Palavras-chave: alagamento, mecanismo de defesa, pinheiro.

\section{INTRODUCTION}

Conifers are long-lived trees and their success can partly be attributed to their potent defense mechanisms against insects and fungi, among them production of resins (Franceschi et al., 2005; Luchi et al. , 2005). Injuries to the resin duct system cause the accumulation of oleoresins at the injury site (Martin et al., 2002), forming a physical barrier against boring insects, which can also act as vectors of pathogenic fungi (Wallin et al., 2003). In Abies grandis, fungal extracts stimulate the production of monoterpene cyclases, enzymes that are involved in the production of oleoresins (Lewinsohn et al., 1994). In addition, genes involved in the metabolic defense mechanisms of plants are synergistically induced by ethylene and methyl jasmontate (Xu et al., 1994). Traumas increase the gene expression of ACC-oxidase, a precursor of ethylene in the resin ducts (Hudgins and Franceschi, 2004; Chae and Kieber, 2005) 
Various stress factors can alter the production of phytohormones and trigger responses modulated by these agents external to the plant (Kerbauy, 2008). Resin flow is a defense response controlled by various environmental factors (Rodrigues et al., 2009). Yamanoto and Kozlowski (1987) observed that in Pinus densiflora seedlings, flooding and application of ethrel, a synthetic precursor of ethylene, stimulated the formation of thickwalled tracheids and induced the formation of resin ducts. The oleoresins of Pinus elliottii are composed of mixtures of terpenoids, particularly turpentine (mono and sesquiterpenes) and rosin (diterpenes), which can be used in solvents, varnishes, flavorings, fragrances, disinfectants, synthetic rubber and glues (Lee et al., 2001; Rodrigues et al., 2009).

Based on reports that increased ethylene levels are caused both by mechanical traumas and flooding, questions arise of whether flooding can increase the production of oleoresins in young Pinus elliottii plants and if it is possible to establish seedling parameters that can be related to the production of resins. The aim of this work was to verify whether flooding increases the output of oleoresins in seedlings and if ethylene stress-induced and other measurable parameters can be related to this production.

\section{MATERIAL AND METHODS}

Pinus elliottii seeds were cooled in the laboratory in a refrigerator and soaked in water for 15 days, after which they were germinated in test tubes $(25 \mathrm{~mL})$ in a mixture of soil-vermiculite (1:1) containing mycorrhizas gathered under mature $P$. elliottii trees. The tubes were watered daily in a greenhouse. When the seedlings reached about $10 \mathrm{~cm}$ in height, they were transplanted to PVC cylinders $(40 \times 100 \mathrm{~cm})$ with drains holes at the bottom and cerrado (savanna) soil was added, fertilized with $3 \mathrm{~g} / \mathrm{L}$ of NPK (5:15:15) enriched with mycorrhizas. When the seedlings reached 12 to 13 months of age, they were divided into 10 treatments of 30 plants each, in asbestos fiber boxes: 1) control without flooding with resin extraction at time zero, 2) control without flooding with resin extraction after 7 days; 3) one week of flooding with resin extraction four days after drainage; 4) one week of flooding with resin extraction 8 days after drainage; 5) control without flooding with resin extraction after 14 days; 6 ) two weeks of flooding with resin extraction 4 days after drainage; 7) two weeks of flooding with resin extraction 8 days after drainage; 8) control without flooding with resin extraction after 21 days; 9) three weeks of flooding with resin extraction 4 days after drainage; and 10) three weeks of flooding with resin extraction 8 days after resin drainage. In all cases the water was drained with a siphon.

The plants were numbered individually in advance and the stem diameter was measured at $2 \mathrm{~cm}$ above the collar. The total seedling height was measured from the base to the tip with a ruler. The resin was extracted by cutting a $V$-shaped incision in the stem about $5 \mathrm{~cm}$ from the base, and the material was collected in a cut-off Eppendorff tube adjusted and tied to the stem. To keep the exudate flowing, an acidic paste was applied on the incision with a spatula, as described by Rodrigues et al. (2008), and the resin was collected for five days. The amount of exudate was quantified by weighing on a precision scale. The data on the stem diameter and height of the seedlings at the start of the experiment and on resin production were adjusted to the normal distribution and/or for homoskedasticity, when necessary, by a specific transformation in each case. Then the data were submitted to parametric analysis of variance (ANOVA) followed by a test to compare the means by the minimum significant difference (MSD at 5\%). Besides this, correlation analysis was performed to identify possible effects of the initial height and stem diameter on the resin production.

\section{RESULTS AND DISCUSSION}

At about one year of age, the Pinus elliottii mycorrhized plants had reached an average height of slightly over $0.5 \mathrm{~m}$ and a stem diameter above the collar of $2 \mathrm{~cm}$. Indeed, the use of mycorrhizas to cultivate this species favors the development of seedlings (Silva et al., 2003). The analysis of variance indicated no significant difference in the stem diameter and height of the seedlings in each treatment, thus ruling out the possibility that these variables may have interfered in the results (Table 1). 
Table 1. Mean stem diameter and height of the Pinus elliottii seedlings used in each treatment (exposed to flooding for 7, 14 and 21 days). The control plants were analyzed at the times corresponding to the flooding treatments.

\begin{tabular}{cccccccc}
\hline & \multicolumn{4}{c}{ Treatments (simulated flooding periods) } \\
\cline { 2 - 7 } & \multicolumn{3}{c}{ Diameter $(\mathrm{mm})$} & \multicolumn{4}{c}{ Height(cm) } \\
\hline Days & 7 & 14 & 21 & 7 & 14 & 21 \\
Mean & 7.35 & 7.36 & 7.33 & 52.28 & 52.69 & 52.28 \\
CV (\%) & 15.3 & 14.4 & 12.6 & 16 & 16.5 & 16.7 \\
P-value & 0.469 & 0.796 & 0.75 & 0.802 & 0.727 & 0.692 \\
Transformation & - & $1 / x$ & - & - & - & - \\
\hline
\end{tabular}

The resin production by the Pinus elliottii seedlings exposed to flooding stress for three weeks increased by $78 \%$ as measured in samples collected four days after drainage. A similar effect (an increase of $\sim 73 \%$ ) oleoresins production was obtained from the seedlings flooded for two weeks also, but with only one week of flooding the increase in resin outputs was not significant $(P=0.923)$. The sampling periods after drainage also affected the results, with the greatest resin production occurring four days after drainage (Figure 1). resin yield was also greater with larger stem diameter of the $P$. elliottii seedlings (Table 2). A larger stem diameter of the $P$. elliottii seedlings was previously shown to be related to a greater increase in the volume of resin ducts in response to stress situations (Yamanoto and Koslowski, 1987; Hudgins and Franceschi, 2004), which means greater capacity to store oleoresins. This effect was also observed for adult trees of this species: the larger the trunk diameter, the greater the resin production is (Rodrigues et al., 2008).

The flooding-induced resin production in Pinus elliottii plants could be also underlie an ethylene production, since the same pattern was observed in corn, where hypoxia of the root system was observed to increase the production of ethylene (Geisler-Lee et al., 2010). Under these conditions, it was found enzymes of the synthesis pathway of this phytohormone, inducing greater production of terpenoids and synthesis of resins. Flooding should not last longer than three weeks, because of the possibility of causing severe damages to the plants, such as leaf shedding, root rot and stunted or halted growth (Kozlowski, 1997). Flooding can also be a useful procedure for selection of plants for growth in the nursery (plants with greater oleoresin expression) and to supplement the parameters for selection of seed sources of resinferous plants. It still remains to be seen whether this mechanism, expressed in the young phase, continues to operate in the adult phase. Experiments are underway to try answering this question in a near future.

Table 2. Pearson correlation coefficient between diameter and height of Pinus elliottii seedlings at the start of the experiments, with the production of resin measured in each treatment by flooding simulation.

\begin{tabular}{ccccc}
\hline $\begin{array}{c}\text { Treatments } \\
\text { (flooding) }\end{array}$ & $\begin{array}{c}\text { Diameter } x \\
\text { Resin Production }\end{array}$ & significant & $\begin{array}{c}\text { Height } x \\
\text { Resin Production }\end{array}$ & significant \\
\hline Control & $10.0 \%$ & $\mathrm{~ns}$ & $6.0 \%$ & $\mathrm{~ns}$ \\
7 days & $32.0 \%$ & $*$ & $0.9 \%$ & $\mathrm{~ns}$ \\
14 days & $34.0 \%$ & $*$ & $9.0 \%$ & $\mathrm{~ns}$ \\
21 days & $15.0 \%$ & $\mathrm{~ns}$ & $16.0 \%$ & $\mathrm{~ns}$ \\
\hline
\end{tabular}

ns $=$ not significant; ${ }^{*}=$ significant at $1 \%$ probability

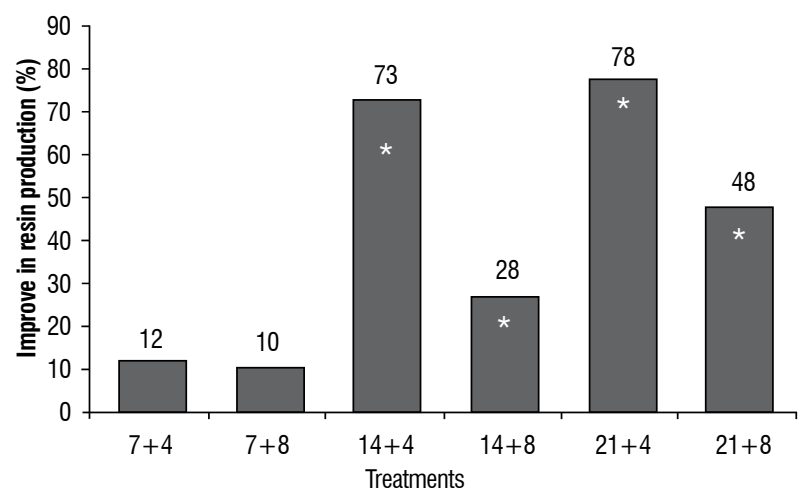

Figure 1. Percentage of increase in resin production of Pinus elliottii seedlings during flooding compared to the yield of unflooded control seedlings. Numbers on the $\mathrm{X}$ axis correspond to flooding time + period of recovery post draining before resin harvest started - all values in days (7,14 and 21 days of flooding simulation and resin harvesting 4 or 8 days after draining) (stars inside bars indicate that increments differ statistically from the respective controls by the DMS test at $5 \%$ probability).

\section{CONCLUSIONS}

It is possible to quantify the resin production of Pinus elliottii plants as young as one year of age. The flooding of young plants of this species for two to three weeks is efficient to increase resin yield by up to $78 \%$.

Acknowledgments: We thank the biologist Arthur G. Fett-Neto for critical reading of the manuscript; the forest engineer Sidney Caldeira for recommendations on the use of 
mycorrhizas and fertilization levels; the agronomist Augusto Souza Martins Filho for supplying the seeds and growing instructions; the biologist Carlos Casali and Ph.D student Ana Beatriz Gatti for help in gathering the data; and the assistant technician Ademir de Paula for help in planting and preserving the plants. This work received funding from the National Council for Scientific and Technological Development (CNPq).

\section{REFERENCES}

Chae HS, Kieber JJ,(2005) Eto Brute? Role of ACS turnover in regulating ethylene biosynthesis. Trends Plant Sci.10:291-296.

Franceschi VR, Krokene P, Christiansen E, Krekling T. (2005) Anatomical and chemical defenses of conifer bark against bark beetles and other pests. New Phytol 167:353-376.

Geisler-Lee J, Caldwell C, Gallie DR.( 2010) Expression of the ethylene biosynthetic machinery in maize roots is regulated in response to hypoxia. J Exp Bot.61:857-871.

Hudgins JW, Franceschi VR.( 2004) Methyl jasmonate-induced ethylene production is responsible for conifer phloem defense responses and reprogramning of stem cambial zone for traumatic resin duct formation. Plant Physiol. 135:2134-2149.

Kerbauy G.( 2008) Fisiologia Vegetal. 2nd ed. Rio de Janeiro. GuanabaraKoogan 431p.

Kozlowski TT.(1997) Responses of woody plants to flooding and salinity. Tree Physiol Monograph, v.1, pp. 1-29.

Lee HJ, Ravn MM, Coates RM. (2001) Synthesis and characterization of abietadiene, levopimararadiene, palustradiene, and neoabietadiene:
Hydrocarbon precursors of the abietane diterpene resin acids. Tetrahedron,.57:6155-6177.

Lewinsohn E, Worden E, Croteau R.(1994) Monoterpene cyclase in Grand fir callus cultures: modulation by elicitors and growth regulators. Phytochem. 36:651-656.

Luchi N, Ma R, Capretti P, Bonello P.(2005). Systemic induction of traumatic resin ducts and resin flow in Australian pine by wounding and inoculation with Sphaeropsis sapinea and Diplodia scrobiculata. Planta, 221:75-84.

Martin DM, Tholl D, Gershenzon J, Bohlmann J.(2002) Methyl jasmonate induces traumatic resin biosynthesis, and terpenoid accumalation in developing xylem of Norway Spruce stems. Plant Physiol. 129:1003-1018.

Rodrigues KCS, Azevedo PCN, Sobreiro LE, Pelissari P, Fett-Neto AG.(2008) Oloresin yield of Pinus elliottii plantations in a subtropical climate: Effect of tree diameter, wound shape and concentration of active adjuvants in resin stimulating paste. Industrial Crops Products, 27:322-327.

Rodrigues KCS, Fett-Neto AG.(2009) Oleoresin yield of Pinus elliottii in a subtropical climate: Seasonal variation and effect of auxin and salicylic acidbased stimulant paste. Industrial Crops Products, .30:316-320.

Silva RF, Antoniolli Zl, Andreazza R.(2003) Produção de mudas de Pinus elliottii Engelm. micorrizados em solo arenoso. Ciencia Florestal, .13:57-65.

Wallin KF, Kolb TE, Skow KR, Wagner MR.(2003) Effects of crown scorch on Poderosa pine resistance to bark beetle in Northern Arizona. Environ Entomol, 32:652-661.

Xu Y, Chang P, Narasimhan ML, Raghothana KG, Haregawa PM, Bressan RA.(1994) Plant Defense genes are synergistically induced by ethylene and methyl jasmonate. Plant Cell, 6:1077-1085.

Yamanoto F, Kozlowski TT.(1987) Effects of flooding, tilting of stems, and ethrel application on growth, stem anatomy and ethylene production of Pinus densiflora seedlings. J Exp Bot, 38:293-310. 